\title{
Orientalist modes of modernism in architecture : Colonial/Postcolonial/Soviet
}

\section{Boris Chukhovich}

Translator. Vladimir Makarov and Valérie Kaen

\section{(2) OpenEdition \\ Journals}

Electronic version

URL: http://journals.openedition.org/edl/728

DOI: $10.4000 /$ edl.728

ISSN: 2296-5084

\section{Publisher}

Université de Lausanne

\section{Printed version}

Date of publication: 15 September 2014

Number of pages: 263-294

ISBN: 978-2-940331-35-2

ISSN: 0014-2026

Electronic reference

Boris Chukhovich, «Orientalist modes of modernism in architecture : Colonial/Postcolonial/Soviet », Études de lettres [Online], 2-3 | 2014, Online since 15 September 2017, connection on 18 December 2020. URL : http://journals.openedition.org/edl/728 ; DOI : https://doi.org/10.4000/edl.728 


\section{ORIENTALIST MODES OF MODERNISM IN ARCHITECTURE: COLONIAL/ POSTCOLONIAL/SOVIET}

This article aims to propose a comparative analysis of modernism in architecture, which appeared at the end of the 19th and especially during the 20th century in colonial Maghreb, postcolonial India and Soviet Central Asia. Building on the notion of double bind, we attempt to explore the contradictory role that modernism played in the modernisation of the way of life in the "Oriental peripheries" of old colonial empires to better understand the peculiarity of the Soviet experience. We find in it some phenomena close to colonial and postcolonial modernist practices, as well as other potentialities inherent in the Communist utopia.

At the turn of the 1960s, architects in various parts of the world were trying out new approaches to city development and thus, to the modernisation of social life. Almost at the same time, there appeared crucial modernist constructions such as the new blocks of municipal housing in Casablanca (1951-1955), Chandigarh, the capital of the state of Punjab (1952-1959), and the centre of Dhaka, the capital of Bangladesh (1962). Similar processes were under way in Soviet Central Asia. It was at this moment that urban projects of new city centres for Tashkent, Ashgabat and numerous other cities arose, as well as the classic constructions of Central Asian modernism (e.g., the Panoramic Cinema in Tashkent or the Karl Marx Library in Ashgabat). What all these examples have in common is the spread of modernism across the periphery of the industrial world, now that it had re-emerged after the avant-garde experiments of the 1920s. It is crucially important to note that all of these peripheries in the collective mind had traditionally been classified as part of the socalled "Orient". 
We think it interesting and useful to compare modernist experimentation in the "Oriental zones" of Western empires to that in Soviet Central Asia. Such a comparison could be useful for the ongoing discussions of how different the centre-periphery relations were in the Soviet Union and in the capitalist empires of the 19th and 20th centuries. Looking for counterparts of Soviet scenarios of architectural development in the "Oriental periphery", we can find some alternatives and parallels to the Soviet experience in the history of colonial Maghreb and postcolonial India. This choice is particularly interesting, since India and Maghreb have both served as an embodiment of the Orient for Britain and France respectively. In its turn, Central Asia, since the start of its colonisation, has been viewed as Russia's "own Orient" in contrast to its status as a European power, while in the Soviet period it was known as "the Soviet East" 1 .

Anyone interested in the local forms of "Oriental modernism" soon faces the paradox that architects could not avoid as well. The original and strongest impetus for modernism was to create a universal language. It is for this reason that one of the most widespread and well-publicized products of modernism in architecture came to be known as the "international style". The universality of modernism was meant to help create a new, modern life based on a radical departure from classical and other traditions. However, the realities of the "non-Western world" and European stereotypes of its "distinctive character" mandated stylistic derivations: the newly-erected cities and constructions had to be pinned to the particular locality and the local agenda. These "peripheral" contexts had to be approached in different ways, and the practices of the "centre" did not work here. It is hard to imagine that the Bauhaus or De Stijl would welcome a particular German or Dutch character in their constructions. Russian constructivists never tried putting their architecture in the context of the Russian tradition as well. On the contrary, their declared objective was to struggle against the imitation of historical architecture as it had been practiced, among other things, by the Style Russe of the early 20th century. At the same time, outside the Western world a question of whether Corbusier's buildings in Chandigarh were

I. See V. Tolz, Russia's Own Orient; S. Gorshenina, “Mnogolikii Vostok russkogo khudozhestvennogo orientalizma"; I. Borozdin (ed.), Khudozhestvennaia kultura Sovetskogo Vostoka; N. Kim, Narodnoe khudozhestvennoe tvorchestvo Sovetskogo Vostoka. 
"Indian", or Kahn's government compound in Dhaka was "Oriental”, was never considered inappropriate. It has, quite on the contrary, always been the most discussed one ${ }^{2}$.

In the USSR, debates around the "national character" of the modernist experience in Central Asia were equally important. It must be mentioned that for many decades, the Stalinist slogan of culture which is "national in form and socialist in content" had only been formally applied to all of USSR's constituent republics. In the case of Russia, Ukraine and Belorussia it had rather a ritual significance than a mandatory status, like a psalm - recited but not deeply comprehended. On the contrary, when speaking of the Caucasus and Central Asia, the canonical formula suddenly acquired the richness and subtlety of a koan, which calls for understanding and interpretation. Dissertations, special issues of academic journals, panels and conferences focused on this formula, and since the 1960 s, when architects had to stop using the "national décor" without justification, the debates have become even more intense. I have mentioned elsewhere that the notion of the "national" in Soviet art, was imbued with Orientalist connotations ${ }^{3}$. Thus, it will be correct to view the articulation of the specific Orientality of Soviet modernism in Central Asia as a particular case within a general process.

Working on non-Western territory, modernist architects can be stated to have worked under an influence of two oppositely directed imperatives - a universalist one and a localising one, centripetal and centrifugal, futurological and traditionalist, functionalist and symbolical. In the light of the theories developed by the Palo Alto school of psychology, this reminds us of the double bind effect. Although some psychologists insist that this idea is only relevant for the psychology of communication, scholars working in other humanities fields have fully appraised the importance and heuristic potential of the paradoxes inherent in the double bind ${ }^{4}$. The meaning of this phenomenon lies in the unresolvable

2. R. Kalia, Chandigarh; B. V. Doshi, Le Corbusier and Louis I. Kahn; M. Le François (dir.), Chandigarh, la ville indienne de Le Corbusier; E. Touchaleaume, G. Moreau, Le Corbusier, Pierre Jeanneret; R. Papillault, Chandigarh et Le Corbusier; V. Prakash, Chandigarh's Le Corbusier; A. Banerji, The Architecture of Corbusier and Kahn in the East, etc.

3. B. Chukhovich, "Building the 'Living East'”.

4. J.-J. Wittezaele (dir.), La double contrainte; J. Nagle, Multiculturalism's Double Bind; K. Oliver, Reading Kristeva, etc. 
dilemma the addressee of the message faces after receiving instructions, one of which is part of the other, but surreptitiously negates it. The addressee cannot come to a "positive solution" that would suit both instructions. Hence the schizophrenic consequences for the addressee's psychic, which are especially grave for children. The community of architects - probably the most pragmatic of all artistic communities has developed the most rational forms of reacting to the contradictory "social mandate". Firstly, the modernist architecture of the "Orient", as a rule, in varying degrees incorporated an answer to both vectors of the double bind. Secondly, critical statements on architecture acquire an important role here. In the texts authored by the architects, as well as in critics' commentaries, silenced and hidden messages spoke as eloquently as those well-articulated and emphasized. Unlike a building which remained relatively unchanged and was often a message addressed to society and even to history, what was said about a construction was stratified in space (a commentary would change to suit the audience) and in time (the same piece of architecture could be diversely interpreted even by its author, depending on the current agenda). Gaps appearing between the building and the commentary meant to either soften the contradiction or emphasize the mismatch between the architectural design and one of the requirements of the double bind, thus giving rise to an illusion that the contradiction could be resolved in the future. As we shall see, the fact that these mechanisms worked well in the tactical sense does not cancel the paradoxical feeling that the "Oriental modernism" came to a deadlock, both in 1920s and 1960s.

\section{Modernism vs orientalism in a colonial context: the case of the Maghreb}

Since the 1950-1960s, the history of architecture has come to be more autonomous from philosophy and social sciences than, say, the history of literature or fine arts. It was probably due to this autonomy that Orientalism in architecture has not been so radically reassessed as it was in literary studies and the history of visual arts after the advent of postcolonial theory. Even now, speaking of Orientalist architecture, critics largely focus on stylistic borrowings or Oriental-themed architectural fantasies, avoiding the discursive arrangement around an architectural 
construction and its building or functioning. Alternative methods have also been tested, though. In 1994, for instance, the Revue du monde musulman et de la Méditerranée devoted a special issue to this problem. Among the modalities of Orientalism, the publication studied not only the formal impact of the Orient on European art, but also the "East" as it was constructed "on the spot" by European architects using the tools of urbanism, but not limited to them only ${ }^{5}$. We consider this turn crucially important, since it shifts the accent towards the semantic core of Orientalism as Edward Said interpreted it: Europe constructs the "Other" while keeping it under colonial power. We agree with Said that the "Orient" was a brainchild of the West. However, it is impossible to ignore that it was colonial architecture and urbanism that changed the environment and material living conditions of the colonised, urging them to adapt to the rules and norms which would suit the European notions of the "Oriental Other". Therefore, while Orientalism in literature and art embodied the images of the East targeted at the European consumer, architecture, like a demiurge, shaped the real "Orientals" and thus was probably the most consistent form of Orientalism. At the same time, it might not have even included any external features of what has come to be known as Orientalist architecture - be it pointed arches or turquoise domes.

Given the whole variety of colonial situations, the case of the Maghreb seems the most attractive for us, as the situations there come closest to their Central Asian counterparts in the historical, economic and cultural aspects. The establishment of French control over Algeria (1830), Tunisia (1881) and Morocco (1912) largely falls in the same period as the conquest of Central Asia in the latter half of the 19th century. Both in Central Asia and northern Africa, colonisations were blessed by the rhetoric of the "civilizing mission" that Europeans undertook for the sake of progress and the ultimate good of the very countries they were conquering. In both cases, colonisers utilised the "return to roots" motive: in the Maghreb, they spoke of re-appropriating "the old Roman world", and in Central Asia, of the legendary "ancestral homeland of the IndoEuropeans". Both regions were associated with the phantasms of "the fusion of the West and East" as expressed by Russian and French utopians. It is of little surprise that we see a lot of similarity between the town

5. C. Bruant, S. Leprun, M. Volait (éds), Figures de l'orientalisme en architecture. 
planning practices exercised by Russian and French colonial authorities. Both in Russian Turkestan and in French Northern Africa, for instance, the practice of building new "European" townships side by side with historic "indigenous" cities ultimately prevailed, which led to the rise of bi-centric urban agglomerations.

Every city of the Maghreb had its own micro-history, which to a certain extent deviates from binary models of postcolonial studies. Moreover, the originally colonial cities of the region have never been dichotomic: besides the "European town" and the medina they had Jewish areas (mellah). It was the eye of the colonisers that saw the cities as binary objects. First, Jews had been classified as autochthones, and their area as a part of "historic cities" ${ }^{6}$, and then it became possible to view them as a "transitional community", something in between Muslims and Europeans. There surely were sufficient differences between areas populated by the urban poor and by the upper classes. We will, however, put aside the details of any particular city and focus on the general logic of the actions within the colonial situations, and on the Orientalist modes characteristic of each of these moves.

Originally, French authorities had been acting in an interventionist and displacing way. Having landed in Algiers, the French troops and engineers started settling down by demolishing the historic area of Lower Casbah to erect the Place d'armes ${ }^{7}$ on its stead. For a long time, the city development progressed by expropriation and absorption of historic areas, always marking the boundaries between the autochthonous and European societies. At the same time, areas newly developed by the French imitated an average 19th century French city, time and resources permitting.

Brutish colonial domination which relied on French bayonets produced opposition even among the colonisers themselves. In particular, this resistance can be seen in the work of Saint-Simonists who considered northern Africa an ideal venue for concluding the much-desired mystical "covenant between the East and West" 8 .

6. Ch. Jelidi, La fabrication d'une ville nouvelle sous le Protectorat français au Maroc (1912-1956).

7. N. Dris, La ville mouvementée, p. 72.

8. S. Almi, Urbanisme et colonisation, p. 25. 
Rejecting the typical colonial Arabophobia, Saint-Simonists called for a joint action of the colonists and the colonised. They helped bring technical and cultural innovations over to Algeria ${ }^{9}$, and their ultimate goal was the fusion of the two communities. Ismayl Urbain, one of the more prominent Saint-Simonists, wrote in this regard:

So, a new race of people, keeping their idioms, customs and various beliefs, will grow under the tutelage of France, confusing its interests, inspired by the same patriotic feeling. It is no longer the unintelligent fusion of races, habits, religious doctrines; it is the association of works to achieve a common goal: peace and well-being ${ }^{10}$.

The ideas and actions of Saint-Simonists were often brought up as an argument against the binarity of traditional postcolonial categories and, ultimately, against vindicating "France's civilising mission". However, it does not mean that this argument cannot be challenged from the same postcolonialist approach. We can agree with the scholars who see SaintSimonists' "good colonisation" as rooted in the colonising process as such and never doubting its foundations ${ }^{11}$. The "covenant between the West and East" had to be brought to life according to the rules developed by the "West" and forcibly accepted by the "East". To make such a fusion possible, the "East" had to learn the lessons of French Enlightenment and accept the "universal values", as well as colonists' way of life. There was no other path for the Islamic community to draw closer to Europeans in both living standards and the perception of life.

The first frontal clash of the two opposite vectors of colonial modernisation produced no positive solution. The demolition of the Muslim city, replaced by European areas, was followed by inevitable conflicts, fears and phobias (it suffices to mention the age-old colonial fear to contract a disease from an autochthone living in "unhygienic" and "insanitary" conditions) ${ }^{12}$. Napoleon III, while on a visit to Algeria (1865), formulated his objective as to "win the sympathy of Arabs by positive benefits" ${ }^{13}$. Following this event, approaches to city development in

9. Ibid., p. 21 and 32.

IO. I. Urbain, Algérie, p. 28 sq.

II. S. H. Ali, "Les Saint-Simoniens en Algérie".

I2. S. Bensmaïl, S. Boughaba, "La ville comme corps, la ville comme hôpital”.

I3. Napoléon III, Lettre sur la politique de la France en Algérie adressée par l'Empereur au Maréchal de Mac Mahon, duc de Magenta, gouverneur de l'Algérie. 
Northern Africa radically changed. After a series of transitional experiments in Tunisia, the Moroccan experience of urbanist Henri Prost came to the forefront. At the initiative of Hubert Lyautey, the first Resident General of the French protectorate, a policy of segregation replaced that of intervention and displacement. To avoid tension and conflict, it was deemed better to separate the European and autochthonous communities in such a way to minimise contact between them within the city space. Autochthonous cities remained enclosed by their fortified walls which formed the city's "natural boundaries", while new areas were developed at a certain distance, beyond the exclusion zone where no construction was permitted (non-aedificandi). This decision, although bordering on apartheid ${ }^{14}$, was thought to have its own "political, economic, sanitary, urban and aesthetic reasons" ${ }^{15}$. Vested with full authority, the administration of the new cities could make large-scale investments in developing the European districts, leaving the old medinas untouched. The very comparison between the dynamically developing areas where Europeans lived with secluded enclaves of the Muslims was an argument in favour of the "progress" which colonialism brought to Africa. Meanwhile, colonists sometimes decorated their constructions with elements of neo-Mauritanian style or with those of the so-called "Moroccan trend" 16 . These conventional forms of Orientalism surely demanded the presence of a referent, which acted as a foil in positioning them as European. Clear testimonies of this can be found in the documents of the period:

With this clear-cut separation, the Resident General wanted, besides the moral, economic and security questions, to preserve the appearance of the indigenous cities, the historical or religious monuments, the picturesque old walls, to finally keep, within its scope, a civilisation untouched for centuries: a heritage forming an incomparable subject of study and a touristic wealth whose importance is considerable ${ }^{17}$.

I4. J. Abu-Lughod, Rabat, Urban Apartheid in Morocco; B. Taylor, "Discontinuité planifiée, villes coloniales modernes au Maroc".

15. La renaissance du Maroc, 1912-1922, p. 362.

I6. F. Béguin, Arabisances, p. 61.

17. La renaissance du Maroc, 1912-1922, p. 363. 
The logic of separation and the border zone which opened the "picturesque views", gave rise to two effects: that of theatricality and museality. A lot has been already written on the theatrical effects of looking through the exclusion zone as "the theatre of domination" 18 . After the "picturesque" character of historic cities had been understood as a factor in improving the quality of life, urban developers started taking heed of the views that would open from newly-developed areas. However, theatricality suggests a more active role for those onstage, and a more passive one for spectators, whereas the medinas rather served as static scenery for vibrant life around them. This is why an analogy with a museum would be more relevant here. It is interesting to note that the museification of a city included not only their spatial environment, but also their way of life. Thus, Jean Gallotti wrote that Morocco had to develop more than just "museum-cities but museums of life" 19 - a testimony of an aspiration towards a highly coherent heritage preservation ${ }^{20}$, which would, besides the urban environment, also include what is now known as the patrimoine immatériel: practices of life, customs and forms of spiritual existence. Here the architects once again face the double bind. On the one hand, to follow up the urban "museum of life" one needs the appropriate observation points; on the other, the very existence of these points or surveillance and observation make such a life impossible. Lyautey understood this problem perfectly:

You know how much the Muslim is jealous of the integrity of his private life, you know the narrow streets, facades without openings behind which life hides from glances, terraces where family life flourishes and that must remain hidden from prying eyes. However, the European house, with its many floors, the higher and higher modern skyscrapers, it is the death of the terrace, undermining traditional life ${ }^{21}$.

Hence the desire to enter a different space where "wide boulevards, water supply systems and electricity, small public gardens and gardens,

I8. H. Vacher, "Villes et colonisation aux XIXe-XXe siècles", p. 379.

I9. J. Gallotti, "La beauté des villes marocaines", p. 808.

20. H. Vacher, "La planification de la sauvegarde et le détour marocain (19121925)".

2I. H. Lyautey, Paroles d'action, p. 452. 
buses and trams", as well as "possible future expansions", would be possible ${ }^{22}$.

The museum, however, is a space where not only values are exposed, but there is also a chance of participation. The preserved Oriental exotics require more than abstract reverence: it demands its own admirers and special routes for admiration. This double bind in its ultimate form manifested itself in Algiers during the 1930s when the authorities were challenged with the issue of preserving the Casbah, following the order of the Governor General ${ }^{23}$. This internal museological challenge helps us better understand the famous Obus plan developed by Le Corbusier in 1931. The master of modernism did everything possible to separate the new city from the Muslim part of the Casbah, following Prost's Moroccan experience. At the same time, he brought the principle of museographic observation of the city to utmost perfection. The new areas he envisioned were to dominate the Upper Casbah so that residents could enjoy the "exotic views" and the sea in the background. Those who would like to reach the shore could do so by cable car leading from the modern district over the Upper Casbah to the sea coast. This very road became the best observation point, and the old city was thus exposed for everyone's view as a museum, as an exotic, still and irrational object. Europeans could observe it from above, staying at a long and safe distance. Prior to the advent of postcolonial studies, this plan could have been considered one of the "great visionary's" urban planning fantasies. Edward Said's book shed new light on the plan. As a French-Algerian-American scholar puts it:

Corbusier's plan establishes constant visual supervision over the local population and clearly marks the hierarchical social order onto the urban image, with the dominating above and the dominated below ${ }^{24}$.

It is also clear that such an extreme attempt to set up a "museum of life" would have turned into a false one: life as usual would have been impossible in the Casbah given the permanent panoptic surveillance from above.

22. Ibid., p. 452 sq.

23. Z. Hakimi, “Le développement de 'l'urbanisme de plan' à Alger durant la période coloniale", p. 75.

24. Z. Çelik, "Le Corbusier, Orientalism, Colonialism”, p. 69. 
From the 1920s to the 1950s, French architects and urbanists in the Maghreb undertook at least two attempts to get out of the museographic colonial deadlock. Casablanca was the venue chosen for both of them. The city's main problem in the 20th century was the quick and steady influx of rural population. The old medina was small and thus could not accommodate all of them, the more so as it was situated close to the most prestigious European districts. Henri Prost found a unique solution for the region. While Europeans had usually preferred to build new cities at a distance from old medinas, Prost suggested a new medina should be built away from the European areas. The challenge was double: on the one hand, the new medina had to preserve local colour and picturesque character, remaining part of the scenery for the European eye. On the other, the area had to be designed, zoned and socially structured in such a way that local residents could accept it as a place of residence. The latter would prevent Europeans from the discomfort of meeting the autochthones every day within the urban space. To imagine "a vision of the Oriental world [...] rendered in all its integrity", architects erected an even more picturesque district - Bousbir - side by side with the new medina. Bousbir, with its brothels, was declaredly built to "remove disordered debauchery" 25 . The stylistic design of both areas was similar. We could view them as arabisances rethought in a modernist way, where more strict and somehow minimalist volumes of white replaced the borrowed or imitated "Oriental details".

The other attempt followed at the end of the 1940s. Once again, it involved the construction of mass and supposedly cheap housing for the city's dramatically growing population. This plan included the Aïn Chock project, a "model city" for the Muslims (Edmond Brion, Paul Busuttil, Antoine Marchisio, 1945-1952), as well as the Carrières Centrales ("Team X": Vladimir Bodiansky, Georges Candilis, Shadrach Woods, 1951-1955). Both projects formed the climactic point of modernism in Morocco. The latter was conspicuous for its principled refusal of any Orientalist forms. Architects managed to get away with the strictest functionalist solutions inherent in the ideology of modernism, as well as with the need to build highly economical mass housing within a limited development space. However, the course of construction showed that even this approach, bereft as it was of historical stylisations, did

25. J.-L. Cohen, M. Eleb, Casablanca, p. 211. 
not deny Orientalism as a way of seeing and structuring the world. Working within the frameworks of earlier practices, Team X members designed standard houses for all three communities: Muslim, Jewish and Christian. The Muslim house was the most closed one, with rooms grouped around the central patio. In the Jewish house, the patio was semi-exposed. The house for Europeans had windows and terraces looking into the open street ${ }^{26}$. The Carrières Centrales were erected in the last years of the protectorate, when the liberation movement was already quite strong. In his memoires, Georges Candilis thus describes a most symptomatic dialogue he had with one of the movement's members:

"Why don't you build for us the same houses as for Europeans, the same houses as in France?"

"Because you live in different conditions form the French! I am trying to find your identity". The response to this was uncompromising: "That is neocolonialism, a far more dangerous paternalism than that of our declared enemies!" 27

The circle of Orientalist modes of modernising the Maghreb actually completes here. Saint-Simonists, the pioneers of "good colonisation", offered a modernisation model based on the "covenant of the West and East" with an imposition of European universalism as an implicit aftermath. Team X modernists tried to diversify their approach and offer a European modernisation to the Europeans, and a Muslim one to the Muslims. They were immediately blamed for this. There is no doubt that unified housing, as a de facto modernist reincarnation of SaintSimonism, would have provoked a new outburst of protest. This centurylong metamorphosis ran step by step into the deadlock of the double bind. Only at the very end of the colonial labyrinth did it become clear that the deadlock is final and hopeless. As long as the imperial domination allows European architects to shape the local architecture at will, their experience will never transcend the boundaries of Orientalism, regardless of whatever formal techniques they use. It seemed that the only solution lay in transforming autochthonous population into fullscale subjects capable of setting their own priorities and modernisation forms.

26. Ibid., p. 326.

27. Quoted from S. Karakyati, "Colonialism and the Critique of Modernity”, p. 45. 


\section{Modernism vs Orientalism in the postcolonial context: the case of Chandigarh}

Chandigarh, with its problematic and divisive status, remains a cult object of modernism. Lovers of architecture from around the world flock to see it, producing texts full of instinctive admiration of the originality of the master architect's design. However, even admirers cannot but note that the universal humanism declared by its author goes against the sad reality: the city does not match the declared social objectives, and its Capitol is empty and more popular with tourists than with local residents. This feeling has been well-summarised by one of the most prominent Indian scholars Ravi Kalia, who did research on the city:

There are two cultures in Chandigarh - the culture of buildings and monuments and the culture of the people. The two cultures are different in content, and the monuments and buildings do not represent the spirit of the people ${ }^{28}$.

He confirms that Chandigarh lacks the fullness of urban life:

It lacks the excitement of Indian streets. It lacks bustling, colourful bazaars. It lacks the noise and din of Lahore. It lacks the intimacy of Delhi. It is a stay-at-home city. It is not Indian. It is the anticity ${ }^{29}$.

These conclusions do not prevent European researchers from continuing to delve further into the myth of "the fantastic potential presented by the inventiveness of Le Corbusier and his revolutionary urban planning" 30 in designing and building Chandigarh. Such polarity of views proves the disjointed state of the discursive fields that have shaped the city and remain its typical feature.

This disruption, however, could not prevent the original convergence. After a long search for an architect to design Punjab's new capital, Indian authorities opted for Le Corbusier - a choice personally endorsed by Jawaharlal Nehru, India’s first Prime Minister. In his turn, Le Corbusier, after a fruitless quest to see his designs implemented in France, Russia, Italy or Algeria, finally found a venue where they could

28. R. Kalia, Chandigarh, p. 152.

29. Ibid.

30. E. Touchaleaume, G. Moreau, Le Corbusier, Pierre Jeanneret, p. 80. 
be brought to life. Both protagonists of the story - the architect and the Prime Minister - agreed that in this case neither being guided by old architecture nor an attempt to create some specific "Indian style" would be acceptable. Nehru formulated his program as follows:

That this city is a new city, symbol of the freedom of India freed from the traditions of the past, expression of the faith of the nation in the future $^{31}$.

This was in line with the architect's plan:

Chandigarh will be the city of trees, flowers and water, of houses as simple as in Homers' time and some splendid very modern buildings where the mathematical rule will reign and in particular Modernism - a measure which is confirmed in every thing here, from simple to $\operatorname{big}^{32}$.

Thus, the Chandigarh project was meant to avoid any external Orientalist features. It was supposed to be an example of new architecture for the new free India.

Nevertheless, postcolonial researchers do not fail to point at both the inconsistencies in the positions of the politician-architect tandem on India and the contradictions inside this tandem. These were analysed, among others, by Vikramaditya Prakash, the author of probably the most consistent deconstructivist study of Chandigarh. According to him :

[...] modernization, thus, was a mimicry of the colonial project, of the aims and aspirations of colonization, imitated and re-legitimized by the English-educated, Indian Elite. If Orientalism was a discourse of the Orient, by and for the Occident; nationalism was its stepsister, a mimicry of the Occident, by and for the post-colony. It was, in this sense, the quintessential postcolonial project ${ }^{33}$.

It is no surprise then that Nehru, with his Cambridge background, approved of Le Corbusier's basic urban approach which was doubtlessly rooted in Ebenezer Howard's concept of the garden city. Most of Le

3I. M. Le François (dir.), Chandigarh, la ville indienne de Le Corbusier, p. 30.

32. N. F. Weber (éd.), C'était le Corbusier, p. 638 sq.

33. V. Prakash, Chandigarh's Le Corbusier, p. 11. 
Corbusier's urban projects, such as the Ville Contemporaine, Plan Voisin or Ville Radieuse, stem from the same conceptual root, bringing greenery into the residential or public area to replace industrial zones and transport. Therefore, when speaking of urbanism, there was no idea to create a new concept of city for the emerging new India, but to adapt and peg the European-born notion to the Indian reality. No wonder that it has given rise to numerous inconsistencies, such as making moving around the city very hard. Le Corbusier had planned to create a "paradise for pedestrians" in contrast to the Western cities overfilled with cars. But Chandigarh had lots of available space and there were very few private cars in India. Due to this, Chandigarh had little actual success, except for providing the most urgently required social and public services to every sector in the city. Ravi Kalia cites the possibility for children to "play, walk to school... usually without crossing the street" in this "safety area" ${ }^{44}$ as the most positive aspect of Chandigarh's sectors. It is surely of huge importance, but we should not forget that since the 1950 s such planning has been a typical feature of every Soviet mikroraion. In this light it becomes clear that the high hopes set on Chandigarh as a symbol of Indian modernisation were largely a disappointment. Living in its historic city centre, with its comfortable villas surrounded by parks, is still a privilege of the Punjabi elite. As of the turn of the new century, this Europeanised elite faces opposition from the ex-rural residents of the neighbouring areas who suffer eviction from their chaotically scattered huts. They are forcibly resettled in camps located at a distance from the city centre under the pretext of preserving the modernist heritage. A postcolonial utopia is transformed into domination typical for "internal colonisations".

Chandigarh's Capitol is different from the city with its mass housing. It is the Capitol which Le Corbusier considered "the highest modernism", and this is the reason why this construction gives the most interesting result in our "Orientalism test". Even a quick glance at the buildings of the Capitol find, there, the plastic experimentation of Le Corbusier's latter period. Their concrete brutalism makes the Capitol akin to the Ronchamp chapel and the La Tourette monastery, the polychromic fillings remind us of the Unité d'Habitation in Marseille, and the brise-soleil, of the Carpenter Centre for the Visual Arts at Harvard

34. R. Kalia, Chandigarh, p. 152. 
University. We thus find it typical and probably the most expressive of Corbusier's work of this period, devoid of any "Indian" or "Oriental" references. It does not mean, though, that Le Corbusier was not interested in the spiritualist categories that Europeans tended to associate with the East.

The sacral image that Le Corbusier gives to such secular buildings as the Assembly and the Palace of Justice deserves special attention. Many researchers have noted their inconsistency with the image of the modern institutions of democratic power. Peter Serenyi saw a similarity in the composition of the Palace of Justice with Le Corbusier's sketches of the Basilica Constantini in Rome. Serenyi treats this as a reference to the fundamental principles of Roman law that the English had brought to India ${ }^{35}$. Other scholars, generally agreeing with Serenyi, nevertheless argue, that despite its monumentalised Anglo-Saxon vision of the separation of powers, Chandigarh has nothing like an agora or forum, or any other place of assembly for citizens ${ }^{36}$. The mastermind of Chandigarh had obviously preferred a concept of power as the assembly of the initiated to the European view of power as a common cause (Res publica). The Capitol, the heart of Chandigarh's civil power, is actually completely separated from the rest of the city. Le Corbusier envisioned a number of artificial hills which fully exclude any visual confluence between the two. The trees and greenery covering the hills leave no space for any possible opening for the Capitol to see the city and vice versa. Prakash noted yet another important detail: being cut off from the city, the government district is transplanted to a wholly different context. On one side of it, rise the Himalayas, on the other, a small settlement that has preserved "the original village patriarchality". It is with this village in the background that most photos of the group of administrative buildings are made. Placed in this context, the buildings lose the routine features of everyday life and are transformed from an "organisation machine" into a "temple of power". Their shape reminds us not of a futuristic project of a new-born state but of archaic forms of primitive art, so frequently referred to in the artistic avant-garde of the 20th century. An exaggeratedly expressive sundial and other mysterious symbolic forms, so conspicuous in the Assembly, are a reference to some forgotten rituals of the sun

35. P. Serenyi, "Timeless but of its Time”, p. 174.

36. Ch. Jencks, "Chandigarh - the next growth", p. 177. 
and fire. An obvious question that arises is: what kind of power can be articulated by these nuances? It is perfectly clear that a modern Western institution disagrees with such a representation. A power which declares itself a movable mechanism for servicing the population enjoys a different set of features - mobility, transparency and functionality - but the Capitol is static, massive and anti-functional. But this disagreement becomes unimportant if we treat the Assembly and the Palace of Justice as temples of sacred rites rather than those of administration, substituting priests for bureaucrats and clerks. Within this logic, it is impossible not to recall the Orientalist discourse which has left its mark on these buildings.

Many researchers hold that Le Corbusier was contemplating two images of Indian modernisation : the one developed by Nehru (an industrial, technocratic modernisation, aiming at a social democracy) and the one by Gandhi (a modernisation that strived to set man's creativity free by reconnecting him with nature in a rural community which had got rid of the capitalist consumption race) ${ }^{37}$. At a certain convergence point, both Le Corbusier and Nehru agreed that the notion of a new ideal city for India must be free from imitating historical traditions. Nehru, who knew well that Le Corbusier was the protagonist of the "machinist revolution", had his reasons for thinking that the architect might be his ally. At the same time, it is clear that in India Le Corbusier experienced intensified vibes of the European avant-garde. These vibes came from its flirtation with the so-called primitive art. It is thus hard not to agree with Prakash that "although they were referring to the same object, ultimately the modernism that was imported by Nehru was not the same that the modernism exported by Le Corbusier" 38 . It is only obvious that in India Le Corbusier changed a vector of modernisation: the one he had been following in Europe was now replaced with its very opposite which led to "l'intemporel et l'indicible". The historical metamorphosis of the double bind can probably explain the internal logic of this sudden and seemingly illogical refocusing.

37. P. Serenyi, “Timeless but of its Time”, p. 177; V. Prakash, Chandigarh's Le Corbusier, p. 9.

38. V. Prakash, Chandigarh's Le Corbusier, p. 21. 


\section{Modernism vs Orientalism in the Soviet context: the case of Central Asia}

Konstantin Melnikov's final draft of the Soviet Pavilion at the 1925 Paris International Exhibition can be considered a forerunner of the meeting between modernism and Orientalism in the Soviet architectural practice. Although this piece of Russian avant-garde is well-known internationally, researchers have never paid attention to the regional emblems of Central Asia it featured. Melnikov chose a camel against a sunlit background with a river and sand dunes as a symbol for Bokhara, and the crescent of Islam stood for the Republic of Turkestan. It is obvious that these emblems displayed typical European prejudice. Central Asia is featured here as a virgin desert opposed to the technological civilisation of the West, or as a focus of medieval devotion, once again in contrast with Western rationality and atheism. A series of such exotic representations in a paradoxical way puts Melnikov's pavilion in the same group with its many counterparts at various colonial exhibitions. The whole first floor of the pavilion was occupied with mini-expositions of the former parts of the Russian Empire, starting with the "Great Russia". But there is surely no talk of a typical capitalist colony. Using Marxist terminology, we can say that the colonial "basis" is topped with the Soviet proletarian "superstructure", as the second floor featured a "workers' club", a "reading room", a "children's home" and "a worker's residence". Thus the first international artistic representation of the USSR symbolically combined two aspects of modernisation: the colonial and the Soviet one.

Probably the best illustration of this duality lies in the Central Asian projects by Viktor Kalmykov. A native of the region who knew the local climate and life well, Kalmykov had been developing a number of conceptual town planning solutions for Turkmenistan, Uzbekistan and Kyrgyzstan since 1930. His approaches were selective and varied. When designing the new Chardjui (1930) which was intended to become a large transport hub as well as an industrial and cultural centre of Turkmenistan, Kalmykov mainly focused on the challenge to adapt the notion of a large city to the hot climate and dust storms. The project has no references to the "cultural uniqueness of the Orient", probably because the population of the city was mainly Russian. On the contrary, the architect densely imbues Chardjui's residential areas with new social 
functions: the various "residential centres" (zhilkombinaty) included, besides standardised blocks for 2-34 people, a lot of public segments: canteens, assembly halls, classrooms, gyms, swimming pools, infant schools, orphanages, cinema halls and libraries ${ }^{39}$. Projects intended for the "nomadic tribes of Kirgizia about to settle down" (1933-1934) were radically different. Besides climatic conditions, they also paid attention to the customs of the nomads who were forced to settle down by the local authorities. In particular, Kalmykov was experimenting with round houses: in his opinion, such a shape would have appealed to the population who had recently been living in yurts (round tents) ${ }^{40}$. Such an approach is perfectly compatible with various projects of modernist housing for Muslims, Jews and Europeans in colonial Morocco, but there are important differences as well. In the colonial world, the construction of housing with a glance to the cultural preferences of the main population groups was one of the tools of strengthening segregation, which made domination and subordination persistent by means of setting up more comfortable and acceptable living conditions. Kalmykov's projects implicitly bear the mark of a very different teleology. They do take into account the difference between cultural habits of various groups, but for each of them, he provides its own type of housing with an inherent potential for emancipation, suggesting a development towards the communist way of life. Russian workers get an offer of new forms of socialist communal lifestyle, and the nomads of yesterday are to enjoy transitional housing to help them adapt to a new social order. Thus the architect does not intend to sustain the existing order, but is quite consciously looking for the most efficient means of transitioning to a different way of life. Ultimately, this new order would have made the segregation and autonomous life of ethnic communities impossible.

In 1926, Moisei Ginzburg wrote a famous article entitled "The national architecture of the peoples of USSR", which came to be the most programmatic constructivist statement on the "Orient". His wide generalisations were based on an analysis of the architectural environment in the cities of Dagestan and Central Asia. The theorist of constructivism comes up with a conclusion that Soviet architects would have to deal here with both the "living Orient" and the "dead Orient".

39. S. Khan-Magomedov, Viktor Kalmykov, p. 47.

40. Ibid., p. 98 sq. 
An example of the latter is the Ulugh Beg Madrasah in Samarkand, which he treated as follows:

The Ulugh Bek Mosque [sic] is a climactic point of a once powerful, but now completely dead period of Uzbekistan's history. It is a tombstone for a bygone period in the Muslims' national development, a period of autocratic Oriental tyrants, of the apogee of Islamism which enslaved the Muslim workers'vital and active force, and of forms which could only reflect the atavistic national idea of the East.

Its counterbalance is "a typical residential area of an Oriental kishlak, aul or city, which is a point of departure for the new national culture of the East" ${ }^{41}$. It is easy to discern that Ginzburg's ideas are based on clichés and reveal the theorist's obvious incompetence in the architecture of Central Asia. He seems to be quite sure that he has a right to dissect the body of culture, separating the "the living" in it from "the dead", the part that has to be destroyed or turned into a museum, from the one which could be spared and used.

Central Asia saw the spread of a certain "demiurgic" Orientalism which rested on the assumption that the historical environment of medieval cities ("the dead Orient", in Ginzburg's terminology) represents a part of the local population's feudal lifestyle which has to be ruthlessly suppressed. Urbanism had the most decisive vote on this issue. Starting from the Tashkent urban development plan (1928-1931), architects have for decades been offering "exterminatory solutions" for the problem of the historic urban environment. However, there were some exceptions. The draft of the Bokhara redevelopment plan (F. Dolgov, 1935-1936) was the first to feature an idea to spare a part of the old town. Dolgov suggested some areas should be saved from demolition and turned into a "historical and cultural reserve" ${ }^{42}$. Similar ideas about Tashkent were voiced during the debates on the 1939 urban development plan. One of the suggestions recommended preserving a part of the old town as a "museum", so that future generations could compare the happy life under socialism with the "dark medieval past" ${ }^{43}$. After a forced break during World War Two, the discussion resumed after the war. Mitkhat

4I. M. Ginzburg, "Natsional'naia arkhitektura narodov SSSR”, p. 113.

42. M. Notkin, Razvitie traditsii planirovochnogo regulirovaniia gorodov Uzbekistana.

43. P. Stronski, Tashkent, p. 70. 
Bulatov, Tashkent's Principal Architect, in particular, was convinced that the old town and its mahalla ${ }^{44}$ structure should be developed rather than demolished, as the mahallah contained elements of communal lifestyle characteristic in communism ${ }^{45}$.

Comparing these plans with the practices of preserving historical heritage in the cities of the Maghreb reveal some similarities and differences. No doubt the Soviet practices were devoid of the segregationist aspect present in French urbanism. While colonial architects strived to distance the Europeans from the Muslims, their Soviet colleagues tried to achieve the opposite effect. All the urban development plans of Central Asian cities drafted since the 1930s in the long term presupposed the unification of "autochthonous" and "European" areas. Like Prost's projects in Morocco, Dolgov's plan to preserve Bokhara's historic centre was linked to the heritage preservation of historic architecture. However, the discourses both designs were embedded in were not the same. If the French colonial urbanists highly valued the "picturesqueness" of the old city, and the views over it improved the "quality of life" in the European areas, the situation in Central Asia during the 1930s turned towards assessing the "progressive role" of historical heritage in the development of the national cultures in USSR's constituent republics. Under this new ideology, the Soviet had to "enrich his memory with all treasures mankind has accumulated", primarily with historic works of culture and arts created by the peoples of the USSR. At the same time, the party's policy on this heritage remained ambiguous: some fragments were declared progressive and others reactionary, and the principles of such differentiation remained unclear.

As for the suggestion to preserve a part of historical Tashkent as a kind of instructive "museum of the life in old times", it was probably the most extravagant Soviet manifestation of Orientalist museography. This scenario differed not only from "museums of life" in the Maghreb, but also from "African villages" displayed at colonial exhibitions. Both the Maghreb "museums of life" and the "African village" exhibitions, while stressing the "backwardness" of colonial peoples, did actually focus on unique, picturesque and exotic aspects in the life of the "aborigines", somewhat aestheticizing it. On the contrary, the ideological

44. Neighbourhood communities in historic cities of Central Asia.

45. P. Stronski, Tashkent, p. 151. 
effect of Tashkent's "museum" of the old town was achieved by displaying the ugliest aspects of the "accursed past". Its objective and aesthetics were, in a sense, akin to those of the concentration camps turned into museums. The problem, however, lay in the fact that the exposed "fragments of the past" had to remain an element of the present: the city block which would have become a museum was supposed to have real residents who would have represented - with some degree of theatricality - "the life in old times". Most likely, the absurdity of this manifestation of the double bind had been understood quite soon. But the repercussions of this project came back 40 years later, when a project to redevelop Kal'kauz (an area within Tashkent's old town) was drafted (Andrei Kosinskii, Gennadii Korobovtsev, 1978).

By the end of the 1970s, most of Tashkent's old town had already been demolished and replaced with a network of modern avenues. The Kal'kauz redevelopment plan, due to a number of architectural landmarks and a picturesque canal flowing through the area, suggested a different approach. For the first time since the 1930s, architects were seriously concerned with the idea that the standard housing that had filled Central Asian cities did not match the cultural traditions of the autochthonous population. They argued as follows:

In Russia, people have always been living within four walls. So, when people of the temperate zone moved into high-rise buildings, the same small houses were actually piled one upon the other. Basically, [...] there was no significant lifestyle change here. In the East, the way of living is absolutely different. They do not live in separate rooms in the East, but in the patios, in open spaces. Therefore, when we push a man of the East into a high-rise building, we change their lifestyle most abruptly ${ }^{46}$.

While preserving the medieval building and the network of crooked alleys around them, the architects planned to surround them with multitiered modern constructions, with dense low-storied zones gradually morphing into 5- and 9-storied areas. The prospect would be crowned with extravagant multi-floor hotels which would serve as observation points for tourists. The overall composition would be shaped as an amphitheatre with the remains of the old town in its focus. Recognising

46. Interv'iu Andreia Kosinskogo, 1975. 
that preservation of the bygone life would be impossible, the architects suggested that the old alleys should host the workshops of artisans - potters, engravers, chisellers - who could make their hand-crafted goods in public view. Thus the old town would have become a theatrical stage; its supposed residents, actors on this stage; and those living in the surrounding high-rise buildings together with the tourists would have been their voyeuristic audience. This idea is somehow similar to a number of previous projects: to the panoptical plan of redeveloping Algiers (1931); to the Maghreb "museums of life"; to the plan of a new medina for Casablanca, with its Orientalist stylisations of modernist architecture; to the theatrical Orientalist "traditional blocks" in the Tashkent development plan of the 1930s; and finally, to Bulatov's project of the "communist mahallah" ${ }^{47}$. This conceptual heteroglossia reveals that the Soviet answer to the challenges of the double bind was probably the most multi-layered, which opens up the way for absolutely opposite treatments of this answer, depending on whether we choose colonial, postcolonial or communist "optic" as our essential standpoint.

Admittedly, even within the described context a modernist thrust towards a new world "without Russias or Latvias" inspired many Central Asian architects to transcend the Orientalist approaches. In particular, this took the form of accepting the "internationalist style". A flagship construction of this style was the Office of the Central Committee, Communist Party of Uzbekistan (1964). This strictly fundamental building, with its transparent façade opening on one of the Uzbek capital's central avenues, was a metaphorical manifest of the "Central Asian thaw", which emphasized accessibility and transparency of power, as well as an optimistic vision of the upcoming nationless communist rearrangement. The architects of the Office of the Central Committee tried to escape from either the Orientalist colonial decorating, familiar from the style of the Stalinist Empire, or from the lure of imitating the "modern temple of power" as designed by Le Corbusier. This surely ran against the demand of a "national form", and as early as in the 1970s the party authorities started to strongly impose more localised approaches by architects.

47. The Kal'kauz redevelopment project featured city blocks divided into zones named "communist mahallahs". 
Among the many derivations of the "international style", Tashkent's Panoramic Cinema (1964) does stand out. The glazed-in rectangular block of its hall adjoins the blind bulk of the auditorium shaped as a cutoff Doric column. On the one hand, there is an emphatic Freudian slip here (Sergo Soutyagin sometimes mentions that this solution came to him in a dream). The slip reveals that the "internationalism" of the cosmopolitan architecture of the 1960s was rooted in a particular locality, once an epicentre of European culture, which for the professional community of Central Asian architects still remained a kind of an aesthetic matrix. On the other, the building perfectly matched the city context and looked very attractive with the old town in the background. But even such a piece of architecture had to pass the discursive evaluation test in order to match the requirements of the Orientalist representativeness of "national architecture". The Panoramic Cinema starts the history of reading intuitive and graphic correlations into the interpretations of Central Asian architecture. These correlations link modern constructions with the regional tradition and justify their innovative character via the mediated connections with the "national form". As researchers put it a decade later:

The contrast of a blind massive volume with a light and transparent one; the dissection of visual perception of the object into a number of interiors, relatively independent but braced together by the dramatic art of dynamic performance; their large-scale articulation of light; the sudden and gradual opening of vistas and frames; the variety of closely intertwining functional zones - all of these features reveal an acutely modern thinking, endowed with the "genes" of seeing and feeling inherited from the local culture of urban development ${ }^{48}$.

The Karl Marx Library in Ashgabat (Abdoulla Akhmedov, 1966-1976), clearly inspired by Le Corbusier's brutalist Indian experiments, deserved the following comment from a critic:

The problem of national form was addressed in a talented and profound way. Even in the general design, with its courtyards and roofed terraces, we can feel the techniques of national architecture [...]. But

48. T. Kadyrova, I. Notkin, "Samobytnost - v splave traditsii i novatorstva”, p. 20. 
all of these stay on the level of general associations, without borrowing forms and details of the old architecture ${ }^{49}$.

Such a shift of meanings, together with the encratic character (Roland Barthes) of the rhetoric used here, is quite typical. Thus, writing on the Gulistan market in Ashgabat (Vladimir Vysotin, 1984), which represented the classic modernist motive of "struggling with the mass", another critic stresses that "we can see here a link to the old traditions of Central Asian cities, where markets were also communication centres, rather than merely trading venues" ${ }^{50}$. One more example can be found in the works of Yuri Parkhov, an architect from Dushanbe, who has been consistently developing two modernist themes: a combination of atomic forms of the parallelepiped and the cylinder, and texturizing constructions with longitudinal horizontal stripes. The comment has it as follows:

The exterior of [his] buildings is laconic, and the brick lining brings up an associative and graphic link with Tajik traditional architecture ${ }^{51}$.

This is how local reality verbally transcoded architecture, according to the rules of the Soviet orientalist discourse.

\section{Conclusion}

We can state that almost all modalities of Orientalism which featured in the approaches utilised by Central Asian architects, had also been tried in different contexts, both colonial (Maghreb) and postcolonial (Chandigarh). The otherness of the Soviet experience in Central Asia lies in the presence of a different teleological perspective, which allowed to construe the experience as a project ultimately aimed at the withering of colonial subordination rather than at a persistent optimisation of the domination and suppression practices. This project meant to establish a new type of relationship which would cancel the difference between the

49. I. Gnedovskii, "Novoe zdanie biblioteki v Ashkhabade”, p. 8.

50. I. Katsnel'son, A. Azizov, E. Vysotskii, Arkhitektura Sovetskoi Turkmenii, p. 202 sq.

5I. V. Veselovskii, R. Mykimov et al., Arkhitektura Sovetskogo Tadzhikistana, p. 195. 
"West" and "East". At the same time, we have to realise that the most radical suggestions of Central Asia's urbanists and architects stayed on paper, and the ones finally brought to life probably did not go further than their counterparts in the Maghreb or India. Therefore, the difference between the Soviet and the colonial lies in the aims rather than the outcomes, or, sometimes, in interpretations rather than in designs.

In this regard, we have to mention another particular feature of the "Soviet Orientalism". It is common knowledge that Edward Said limited his analysis to the experience of only two colonial powers: Great Britain and France ${ }^{52}$. The Soviet Orientalism stemmed from the Russian experience which had its own idiosyncrasies. Russian Orientalists argued (more insistently than their Western colleagues) that the West and the East are not actually divided by an insurmountable wall of binary dichotomies. Long before Said, they postulated that the "West" and "East" are historically determined mental constructs, and the essentialist split between them is linked to the imperialist interests of colonial powers. This position quickly became the official stance of the Soviet humanities, as stated in the Stalin-era edition of the Great Soviet Encyclopaedia ${ }^{53}$. Although Marxism did distinguish between various levels of "development" of this or that culture according to the state of their "basic economic relations", the Soviet scholarship, being built on the principles of "class-based analysis", consistently rejected essentialist racial prejudice. In the prospect of the future fusion of all nations that would leave no place for any ethnic or racial superiority, any local configuration of power relations, including the ones which involved violence by the "European centre" against the "Asian periphery", looked different from those based on classic colonial domination. This optic of power should not be overlooked or ignored when dealing with local architectural and urban practices. It should not also be considered the only possible one, as it clearly follows from the cross analysis of modernism in Soviet Central Asia and the colonial Maghreb.

The architecture of Soviet Central Asia has always been viewed as opposed to Russian colonial urbanism. This opposition highlighted, on the one hand, Russia's imperial domination, and on the other, capitalism's class-based antagonisms. Today this twofold contradistinction

52. E. Said, Orientalism and Culture and Imperialism.

53. See V. Tolz, Russia's Own Orient. 
has come to be associated with postcolonial criticism. In reality, many ex-colonies (such as India, Tunisia and Algeria), having gained their independence, declared the same priorities: the struggle against capitalism's implications and against inequality of classes. While Tunisia and Algeria followed in the wake of the Soviet-type single-party system, Nehru attempted to combine a planned economy with democratic rule. In this context, the Soviet could be viewed as a certain version of the postcolonial. Its uniqueness lay, on the one hand, in its reliance on the anticolonial discourse, and on the other, on the Western project of modernisation, on Marxism transplanted to Central Asia by the "bayonets of Bolshevism". It is easy to view this paradox as a new spiral of the double bind which incorporates both the radical demand to dismantle colonial relations and new forms of the domination that the "European centre" exercises over the "Oriental periphery". It is, although, common knowledge that postcoloniality does not come coupled with the full and final destruction of coloniality. Instead, it offers new clues to understanding the latter. The Soviet is the postcolonial not least because its anti-imperialist and internationalist ardour would have been impossible in the framework of official culture of a colonial power. This is probably why the modalities of Orientalism which are explicit in colonial contexts, telles quelles, have continued to exist in a latent form in Soviet culture, as it is typical for the postcolonial. Orientalism in the works of the Soviet modernists, like in Le Corbusier's designs, has to be disentangled from the assemblage of texts and objects by means of a deconstructivist analysis. Howsoever evident some parallels to the colonial experience would seem, this material resists a direct association with Orientalism. Likewise, Orientalist undertones and reverberations can never be fully excluded from it.

Boris Chukhovich UQAM

Translated by Vladimir Makarov, revised by Valérie Kaen 


\section{BIBLIOGRAPHY}

\section{Sources}

Interv'iu Andreia Kosinskogo, dokumentalnyi film A. Grishro, Poisk $i$ traditsii (Uchebnaia kinostudiia VGIK, 1975).

\section{References}

Abu-Lughod, Janet, Rabat: Urban Apartheid in Morocco, Princeton, Princeton University Press, 1980.

Ali, Smaïl Hadj, "Les Saint-Simoniens en Algérie: Les réseaux de 'l'association' comme 'réseaux de la soumission'” (1), El Watan, 31 août 2006: <http://www.algeria-watch.org/fr/article/hist/ colonialisme/saint_simoniens.htm> (accessed 15.10.2013).

Almi, Saïd, Urbanisme et colonisation: Présence française en Algérie, Liège, Editions Mardaga, 2002.

BanerjI, Anupam, The Architecture of Corbusier and Kahn in the East: A Philosophical Inquiry, Lewiston/Queenston/Lampeter, The Edwin Mellen Press, 2001.

BéGUin, François, Arabisances: décor architectural et tracé urbain en Afrique du Nord. 1830-1950, Paris, Dunod, 1983.

Bensmaïl, Sadri, Boughaba, Salwa, "La ville comme corps, la ville comme hôpital: Contrôle et rationalisation des espaces et des corps au service d'une Algérie coloniale", in Le devenir nucléaire au Moyen-Orient. Quel arbitrage?, Paris, L'Harmattan, 2009, p. 135-160.

Borozdin, Il'ia (ed.), Khudozhestvennaia kultura Sovetskogo Vostoka, Moscow/Leningrad, Academia, 1931.

Bruant, C., Leprun, S., Volait, M. (éds), Figures de l'orientalisme en architecture, Revue du monde musulman et de la Méditerranée, 73-74 (1994).

Cattedra, Rafaele, Garret, Pascal, Miller, Catherine, Patrimoines en situation: constructions et usages en différents contextes urbains, Beyrouth, Presses de l'Ifpo, 2001. 
Çelık, Zeynep, “Le Corbusier, Orientalism, Colonialism”, Assemblage, 17 (1992), p. 59-77.

Chuкhovich, Boris, "Building the 'Living East'”, in Soviet Modernism 1955-1991: Unknown History, ed. by Katharina Ritter, Ekaterina Shapiro-Obermair, Dietmar Steiner et al., Vienna, Park Books, 2012, p. 215-231.

Cohen, Jean-Louis, Eleb, Monique, Casablanca: mythes et figures d'une aventure urbaine, Paris, Hazan, 2004.

Doshi, Balkrishna V., Le Corbusier and Louis I. Kahn: The Acrobat and the Yogi of Architecture, Ahmedabad, Vastru-Shilpa Foundation, 1990.

Dris, Nassima, La ville mouvementée: Espace public, Centralité, mémoire urbaine à Alger, Paris/Budapest/Torino, L'Harmattan, 2001.

Gallotti, Jean, "La beauté des villes marocaines", L'Art Vivant, 140 (1930), p. 804-808.

Ginzburg, Moisei, "Natsional'naia arkhitektura narodov SSSR", Sovremennaia arkhitektura, 5-6 (1926), p. 113-114.

GnedovskiI, Iurii, "Novoe zdanie biblioteki v Ashkhabade”, Sovetskaia Arkhitektura, 6 (1976), p. 2-8.

Gorshenina, Svetlana, "Mnogolikij Vostok russkogo khudozhestvennogo orientalizma (XVIII-nachalo XX veka)", Kul'turnye tsennosti, 2004-2006, Sankt-Peterburg, Filologicheskij fakultet Sankt-Peterburgskogo gosudarstvennogo universiteta, 2008, p. 61-77.

Hakimi, Zohra, "Le développement de 'l'urbanisme de plan' à l'Alger durant la période coloniale", in Villes coloniales aux XIX'e-XX $X^{e}$ siècles: d'un sujet d'action à un objet d'histoire (Algérie, Maroc, Libye et Iran), éd. par Hélène Vacher, Paris, Maisonneuve et Larose, 2006, p. 59-81.

Jelidi, Charlotte, La fabrication d'une ville nouvelle sous le Protectorat français au Maroc (1912-1956): Fès-nouvelle, thèse de doctorat en histoire, Université de Tours, 2007.

Jencks, Charles, "Chandigarh - the next growth", in Celebrating Chandigarh: 50 Years of the Idea, New Delhi, Chandigarh Perspectives, 2002, p. 171-181.

Kadyrova, Tulkinoi, NotKin, Iosif, "Samobytnost - v splave traditsii i novatorstva”, Arkhitektura SSSR, 9 (1974), p. 17-20. 
Kalia, Ravi, Chandigarh: The Making of an Indian City, Delhi/Calcutta/ Chennai/Mumbai, Oxford University Press, 1987.

Karakayati, Serhat, "Colonialism and the Critique of Modernity", in Colonial Modern: Aesthetics of the Past, Rebellions for the Future, ed. by Tom Avermaete, Karakayali Serhat, Marion von Osten, London, Black Dog Publishing, 2010, p. 38-47.

Katsnel'son, Iulii, Azızov, Agliman, Vysotskiı, Evgenii, Arkhitektura Sovetskoj Turkmenii, Moscow, Stroiizdat, 1986.

Khan-Magomedov, Selim, Viktor Kalmykov, Moscow, S. E. Gordeev, 2011.

Kim, Nikofor, Narodnoe khudozhestvennoe tvorchestvo Sovetskogo Vostoka: ocherki istorii massovogo teatral'nogo iskusstva Srednej Azii,

Moscow, Nauka, Glavnaia redaktsyia vostochnoi literatury, 1985.

La renaissance du Maroc, 1912-1922: Dix ans de protectorat, publication de la Résidence générale de la République française au Maroc, Rabat/Paris, Imprimerie Marc Texier, 1922.

Le François, Michèle (dir.), Chandigarh, la ville indienne de Le Corbusier, Paris, Somogy Editions, 2002.

Lyautey, Hubert, Paroles d'action: Madagascar - Sud-Oranais - Oran Maroc (1900-1926), Paris, Armand Colin, 1927.

Nagle, John, Multiculturalism's Double Bind: Creating Inclusivity, Cosmopolitanism and Difference, Farnham/Burlington, Ashgate Publishing Limited, 2009.

NApOLÉON III, Lettre sur la politique de la France en Algérie adressée par l'Empereur au Maréchal de Mac Mahon, duc de Magenta, gouverneur de l'Algérie, Paris, Imprimerie impériale, 1865.

Notкin, Mark, Razvitie traditsii planirovochnogo regulirovaniia gorodov Uzbekistana, Dissertatsiia na soiskanie uchenoj stepeni kandidata arkhitektury, Tashkent, Tashkentskij arkhitekturno-stroitel'nyj institut, 1994.

Oliver, Kelly, Reading Kristeva: Unraveling the Double-bind, Bloomington, Indiana University Press, 1993.

Papillault, Rémi, Chandigarh et Le Corbusier: Création d'une ville en Inde 1950-1965, Toulouse, Editions Poḯsis-AERA, 2011.

Prakash, Vikramaditya, Chandigarh's Le Corbusier: The Struggle for Modernity in Postcolonial India, Seattle/London, University of Washington Press, 2002.

SAID, Edward, Orientalism, New York, Vintage Books, 1978. 
—, Culture and Imperialism, New York, Alfred A. Knopf, 1993.

Serenyi, Peter, "Timeless but of its Time: Le Corbusier's Architecture in India”, in Le Corbusier, ed. by Harold Allen Brooks, Reyner Banham et al., Princeton/New Jersey, Princeton University Press, 1987, p. 163-182.

Stronski, Paul, Tashkent: Forging a Soviet City, 1930-1966, Pittsburgh, University of Pittsburgh Press, 2010.

TAYlor, Brian, "Discontinuité planifiée, villes coloniales modernes au Maroc", Cahiers de la Recherche Architecturale, 9 (1982), p. 44-63.

Tolz, Vera, Russia's Own Orient: The Politics of Identity and Oriental Studies in the Late Imperial and Early Soviet Periods, Oxford, Oxford University Press, 2011.

Touchaleaume, Eric, Moreau, Gérald, Le Corbusier, Pierre Jeanneret: l'aventure indienne, Paris/Montreuil, Editions Eric Touchaleaume/ Galerie 54 - Gourcuff Gradenigo, 2010.

Urbain, Ismayl, Algérie. Du Gouvernement des tribus. Chrétiens et musulmans, Français et Algériens, Paris, Just Rouvier, 1848.

VACHer, Hélène, "La planification de la sauvegarde et le détour marocain (1912-1925)", in Patrimoines en situation: constructions et usages en différents contextes urbains, éd. par Raffaele Cattedra, Pascal Garret, Catherine Miller, Beyrouth, Presses de l'Ifpo, 2001: <http://books.openedition.org/ifpo/879> (accessed 17.04.2014).

- " "Villes et colonisation aux XIX" $-\mathrm{XX}^{\mathrm{e}}$ siècles: approches et problématiques d'un avatar urbain depuis la Seconde Guerre mondiale", in Villes rattachées, villes reconfigurées. $X V I^{e}-X X^{e}$ siècles, Actes du colloque de Tours, les 13, 14 et 15 décembre 2001, éd. par Denise Turrel, Tours, Presses Universitaires François Rabelais, 2003, p. 367-386.

VeselovsкiI, Vsevolod, Myкimov, Rustam et al., Arkhitektura Sovetskogo Tadzhikistana, Moscow, Stroiizdat, 1987.

Weber, Nicholas Fox (ed.), C'était Le Corbusier, trad. de l'anglais par O. Demange et M.-F. de Paloméra, Paris, Fayard, 2009.

Wittezaele, Jean-Jacques (dir.), La double contrainte. L'influence des paradoxes de Bateson en Sciences humaines, Bruxelles, Editions De Boeck, 2008. 
